Article

\title{
YouTube Videos in the Virtual Flipped Classroom Model Using Brain Signals and Facial Expressions
}

\author{
María Artemisa Sangermán Jiménez ${ }^{1,2, *}$, Pedro Ponce ${ }^{3} \mathbb{D}$ and Esteban Vázquez-Cano ${ }^{4}$ D \\ 1 Department of Spanish and Literature, HS, Tecnologico de Monterrey, 222 Calle Del Puente, \\ Tlalpan, Mexico City 14380, Mexico \\ 2 Escuela Internacional de Doctorado, Universidad Nacional de Educación a Distancia, 14 Juan del Rosal, \\ 28040 Madrid, Spain \\ 3 TecLabs, Vicerrectoría de Investigación y Transferencia de Tecnología, Tecnologico de Monterrey, \\ 222 Calle Del Puente, Tlalpan, Mexico City 14380, Mexico; pedro.ponce@tec.mx \\ 4 Faculty of Education, Universidad Nacional de Educación a Distancia, 14 Juan del Rosal, \\ 28040 Madrid, Spain; evazquez@edu.uned.es \\ * Correspondence: msangerma2@alumno.uned.es
}

check for updates

Citation: Sangermán Jiménez, M.A.; Ponce, P.; Vázquez-Cano, E.

YouTube Videos in the Virtual Flipped Classroom Model Using Brain Signals and Facial Expressions. Future Internet 2021, 13, 224. https: / / doi.org/10.3390/fi13090224

Academic Editor: Laurent Moccozet

Received: 29 July 2021

Accepted: 26 August 2021

Published: 30 August 2021

Publisher's Note: MDPI stays neutral with regard to jurisdictional claims in published maps and institutional affiliations.

Copyright: (c) 2021 by the authors. Licensee MDPI, Basel, Switzerland. This article is an open access article distributed under the terms and conditions of the Creative Commons Attribution (CC BY) license (https:// creativecommons.org/licenses/by/ $4.0 /)$.

\begin{abstract}
As a result of the confinement due to the COVID-19 pandemic, various educational institutions migrated their face-to-face teaching modality to a virtual modality. This article presents the implementation of the Flipped Classroom model in a completely virtual format to develop grammatical competency in Spanish. The model used videos from YouTube, one of the leading global social network platforms, and the videoconferencing system Zoom, the tool selected by the studied educational institution to continue academic operations during the health confinement. The model was enriched with the Index for Learning Style test to provide more differentiated teaching. This study showed considerable improvement in the academic performance of high school students taking a Spanish course at the Mexico City campus of Tecnologico de Monterrey. Of the total sample, 98\% increased their score by between 2 and 46 points, from a total of 100, in their grammatical competency in Spanish. Additionally, the student satisfaction survey showed that more than $90 \%$ considered the course methodology beneficial for developing their grammatical competency in Spanish. This study demonstrates the potential of the Flipped Classroom model in a virtual format. This teaching structure using the Flipped Classroom model could be replicated in various educational settings and for different areas of knowledge.
\end{abstract}

Keywords: educational innovation; higher education; flipped classroom; virtual education; learning styles

\section{Introduction}

\subsection{The Flipped Classroom Model}

During the past ten years, the Flipped Classroom concept has become increasingly popular. This model has transformed the teaching-learning process wherever it has been implemented. It is an educational model in which the learning content is not presented during class time but is learned by the students before class through various means (mainly digital) provided by the teacher. This ensures class time can be devoted to active learning through exercises, problem-solving, practical activities, and collaborative projects [1].

In this blended teaching model, learning activities take place in two stages: learning outside the classroom and learning in the classroom, in that order. As mentioned above, in the learning phase in the classroom, activities are carried out to reinforce the knowledge acquired previously. This allows the teacher to focus on the low cognitive abilities of students and make class time more productive, with learning activities that are active, interactive, and meaningful. Learning outside the classroom provides opportunities for students to study independently before class, according to their needs [2]. 
The Flipped Classroom concept can be summarized simply as follows: activities that are traditionally undertaken in class are performed at home, and those traditionally undertaken as homework are completed in class [3]. However, the use of this model is complex and enriching. According to Thai, De Wever, and Valcke [4], students can become more competent working under the Flipped Classroom model because it allows them to process information at their own pace and facilitates independent thinking as they tackle complex content.

Competency is accomplished by allowing students to review the submitted material repeatedly as required. Videos allow pausing, going back, and reviewing as many times as necessary. Repeated exposure to learning resources strengthens and deepens students ${ }^{\prime}$ understanding [5]. Each student self-regulates and progresses through the material to master the content. They can also work with others in small groups for mutual support. In face-to-face sessions, the teacher attends the students individually or in small groups [3]. Additionally, the teacher reviews content in greater depth during class activities to consolidate knowledge. The Flipped Classroom allows more focused and personalized attention to be paid to the students [5].

Because the teacher is present when the student needs support, this model establishes a framework to ensure that students receive a personalized education tailored to their individual needs. It has previously been proven that personalized follow-up and individualized accompaniment promotes students' learning processes [6]. Students do not require the teacher to be present to talk to them and provide content they can obtain in their own time. Rather, they need the teacher to be physically present when they become stuck and require individual help [3].

Figure 1 illustrates the teaching process in the Flipped Classroom model.

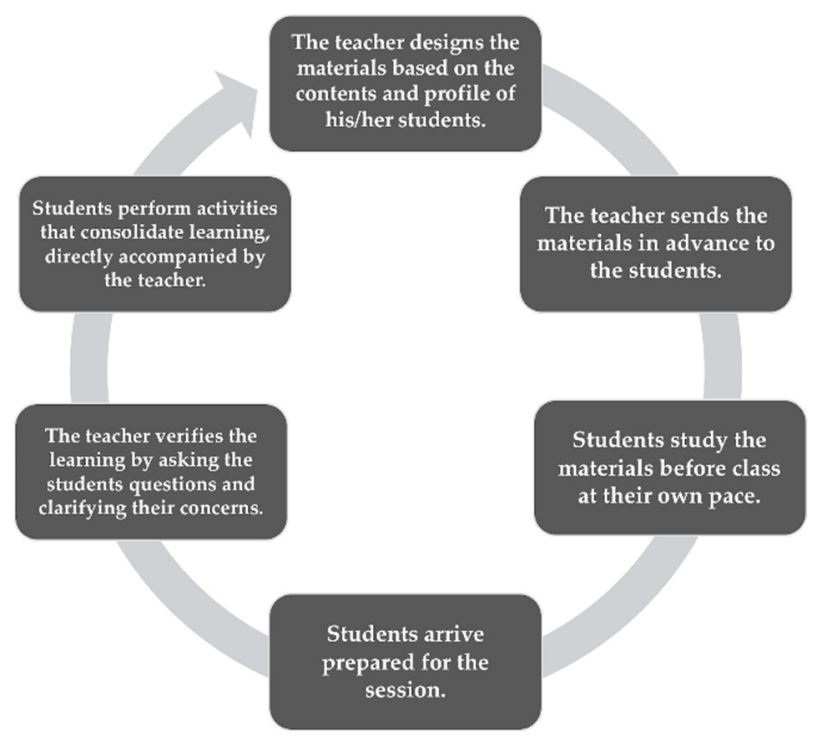

Figure 1. The teaching process in the Flipped Classroom model.

Aligned with the above, Chen Hsieh, $\mathrm{Wu}$, and Marek [5] note that the Flipped Classroom model motivates students to learn, improves their skills, and increases their competency, involvement in learning tasks, and activity in the classroom. It transforms students into self-directed learners of skills, and students acquire more knowledge and competency than in the traditional model [3].

In addition, Bergmann and Sams [7], the creators of the Flipped Classroom model, note a number of reasons to transform traditional education into a Flipped Classroom. The authors mention that the traditional model's significant weakness is that not all students come to class prepared to learn. Some lack the proper background or interest in the subject, or have become disenchanted with the current educational model. In contrast, the Flipped Classroom model: 
1. Teaches students to take responsibility for their learning.

2. Allows a more personalized means of teaching.

3. Allows direct teaching to be synchronous, making it possible to differentiate among the students.

4. Makes learning the focus of the class.

5. Provides students immediate feedback and reduces the teacher's role.

6. Provides leveling opportunities.

7. Allows the assimilation of contents by different means.

8. Provides multiple opportunities to check for understanding.

9. Transforms the role of the teacher.

10. Teaches students the value of learning, rather than just going to school to pass.

11. Is easy to reproduce, adapt, and personalize.

12. Increases personal interactions with the teacher.

13. Ensures that all students become involved.

14. Makes hands-on activities more enjoyable.

15. Increases interest in teacher demonstrations.

16. Makes it easier for teachers to help students.

Table 1 presents a comparison of the advantages and disadvantages of the Flipped Classroom model and traditional teaching.

Table 1. Advantages and disadvantages of the Flipped Classroom model and traditional teaching.

\begin{tabular}{l}
\multicolumn{1}{c}{ Advantage } \\
\hline $\begin{array}{l}\text { Students arrive prepared for } \\
\text { the session. }\end{array}$ \\
The student learns at his own \\
pace because he can review \\
the contents in the specifically \\
designed materials \\
multiple times.
\end{tabular}

\section{The student has the} opportunity to process the knowledge in advance for its application later in the session.

The on-site teacher directly monitors the learning activities.

Differentiated instruction is applied because the model requires monitoring of student performance in on-site activities.

The teacher improvises little; the model forces planning.

There is always time to consolidate learning because the contents are reviewed beforehand.

\section{Traditional Teaching}

Advantage

Disadvantage

More time is required for students to prepare ahead of time.

The teacher spends time designing additional materials or searching for and becoming familiar with them.

More time is required for students to review materials in advance.

The class demands more attention and effort from the teacher.

The class demands more work for the teacher for individualized follow-up.

The model demands more time from the teacher, at least in its implementation.

More time is required for students to review content in advance and free up time for consolidation.
Students are not required to invest additional time before class for their preparation.

No extra time is required for the teacher to design additional materials or search for and become familiar with them. He teaches the class with his knowledge.

Students are not required to invest additional time before class to do their work during class. They learn during class.

The teacher spends less time monitoring activities.

The class is primarily expository and does not demand as much individualized follow-up by the teacher.

The model does not demand that the teacher spend too much time planning.

Students are not required to invest additional time before class to review content.
Students do not know what they will learn.

The student must learn at the speed that the teacher teaches, relying only on the notes that they are able to take.

The student is forced to apply the knowledge immediately after the teacher's presentation.

Learning activities carried out outside of class are not directly monitored. It does not allow a personalized follow-up during the activities as they are mainly done outside of class.

The teacher can improvise all the time by relying solely on the presentation.

The presentation of the contents in class and incorporating activities in the same session limit the time to consolidate. 
This model can be implemented using various physical and virtual materials: videos, infographics, podcasts, books, web pages, manuals, booklets, brochures, cards, and others. In the present study, the materials sent to the students for the acquisition of knowledge were videos designed by the group of teachers involved. According to Bergmann and Sams [7], planning a class under the Flipped Classroom model using videos requires planning the lesson, recording the video, editing it, and posting it (see Figure 2):

1. Plan the lesson: Determine the objective of the class, establish the contents, design the sequence (beginning, development, closure) and the learning activities that should be included, in addition to their evaluation. Gather the necessary components (sometimes it is necessary to investigate the subject to develop it, prepare tables, get images, etc.).

2. Record the video: The video can be recorded by directly speaking to the camera in a digital presentation using voice or by designing the video using an available tool.

3. Edit the video: To achieve higher quality and a more attractive product.

4. Post the video: The method of distributing the videos to the students depends on the policies of the educational institutions. Some have private platforms for this and specific policies that prevent posting their teachers' materials on public sites. If the institution allows it, the videos can be placed on various public platforms, including social networks such as YouTube, Instagram, and Facebook.

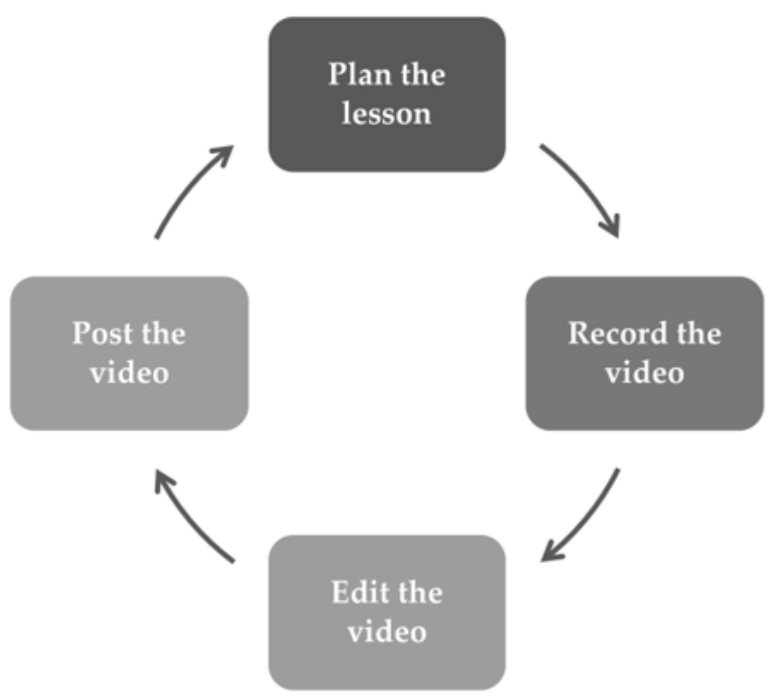

Figure 2. The process of planning a class under the Flipped Classroom model using videos.

\subsection{The Flipped Classroom Model in the Development of Grammatical Competency}

There are several examples of the implementation of this model in various areas of knowledge. This section discusses studies carried out in which the flipped classroom model was explicitly used to develop linguistic competency, not only in the Spanish language, but also in languages.

The Flipped Classroom model was implemented in Ecuador to develop Spanish proficiency in writing among International Baccalaureate (high school) students [8]. This decision was part of a didactic strategy to improve the teaching-learning process of these students. The model was implemented to combine virtual synchronous and asynchronous activities to provide continuity to the program. The researchers concluded that the Flipped Classroom model allowed positive results in the teaching-learning process and was accepted by the students. This study found that this model promotes a dynamic environment, collaborative work, meaningful learning, and self-regulation of learning. It also boosts the commitment and interest of the students in the discipline while preserving their motivation. 
In Spain, another study was carried out in which the Flipped Classroom model was applied to develop linguistic competency among students in the fifth grade of primary education [9]. The results showed an increase in the students' motivation towards learning, which impacted their learning results, as seen in a notable and outstanding increase in the participants' grades. Advances were observed in oral and written expression. The students were very comfortable handling digital devices and understood the possibilities that they offer for learning. The need for direct explanations by the teacher decreased, and the self-management of learning improved. The study revealed that this model notably improves students' academic performance in developing linguistic competency.

Another example of the implementation of this model is a Russian study to develop communicative competence in the teaching of Spanish as a foreign language [10]. The teachers used a selection of videos in Spanish from the YouTube EDU platform as learning materials for study outside of class time. The researchers concluded that the Flipped Classroom model brings several advantages: more time for personalized interaction between teacher and student, increased responsibility and self-sufficiency of the students, and the development of the teacher's capacity to create mini-video classes. Moreover, the model lets each student work according to their rhythm, increases creativity and critical thinking, positively transforms relationships between teachers and students, motivates students, and improves the classroom environment (making it more friendly and comfortable, and allowing better concentration).

As mentioned at the beginning of this section, the Flipped Classroom model has also been used to develop communicative competency in other languages. Such is the case of a study in Latin America to teach English at the baccalaureate level [11]. The study aimed to contrast the development of grammatical competency in the Flipped Classroom model with that of conventional education. The study was carried out with a control group and an experimental group. A test was applied to measure grammatical competency before and after the experiment to validate the English level of the two groups of students. The results showed a significant increase in the development of grammatical competency in the students with whom the flipped classroom was used. Additionally, a survey was applied to determine the students' perception of the Flipped Classroom model, which concluded that this methodology positively impacted their perception. The students' responses revealed that the Flipped Classroom helped them build their learning.

Similarly, the Flipped Classroom model has been studied to develop linguistic competency in the French language. An analysis published in Colombia [12] confirms the benefits of this model for teaching foreign languages, specifically French. According to the authors, this model favors the development of grammatical competency through the practice of grammar structures and vocabulary previously studied at home using digital tools and the Internet. Within the physical classroom, applications were used for interactive activities among students to promote learning the language. The authors affirm that lexical, grammatical, phonological, and semantic skills can be developed in this model because it allows students to manage their learning outside of class and consolidate it in face-to-face sessions through interactions with others. The model promotes language communication by managing class time to focus on language interaction, rather than only content. As in other studies, this highlights the potential of this model to motivate students to learn in their disciplines. A summary regarding the contribution of these studies and the present study is shown in Table 2. 
Table 2. Contribution of the studies provided vs. contribution of the present study regarding the application of the Flipped Classroom model.

\begin{tabular}{|c|c|c|}
\hline \multicolumn{3}{|c|}{ Contribution of the Studies Provided vs. Contribution of the Present Study } \\
\hline Region & Contribution & Present Study \\
\hline Ecuador & $\begin{array}{l}\text { This study describes how the model } \\
\text { can be implemented in a completely } \\
\text { virtual format and reinforced that this } \\
\text { model improves collaboration, } \\
\text { meaningful learning, } \\
\text { self-management, commitment, } \\
\text { and motivation. }\end{array}$ & \multirow{5}{*}{$\begin{array}{l}\text { This study is notably related } \\
\text { to the international studies' } \\
\text { contributions because it } \\
\text { reinforces several of their } \\
\text { findings. However, this study } \\
\text { makes a very important } \\
\text { contribution: it shows the } \\
\text { methodology to follow } \\
\text { sequentially to implement the } \\
\text { model in a virtual format. } \\
\text { This allows the model to be } \\
\text { implemented in line with all } \\
\text { of the recommendations } \\
\text { presented here. }\end{array}$} \\
\hline Spain & $\begin{array}{l}\text { This study reinforced that the model } \\
\text { generates notable improvements in } \\
\text { academic performance and makes } \\
\text { students more independent. }\end{array}$ & \\
\hline Russia & $\begin{array}{l}\text { This study reinforced that the model } \\
\text { allows a more personalized } \\
\text { mentoring and an environment that } \\
\text { helps teachers to be closer to the } \\
\text { students. It found that the model } \\
\text { develops the teacher's ability to } \\
\text { synthesize their lessons. }\end{array}$ & \\
\hline Latin America & $\begin{array}{l}\text { This study reinforced that the model } \\
\text { is well received by students, and also } \\
\text { makes them more independent and } \\
\text { better managers of their } \\
\text { own learning. }\end{array}$ & \\
\hline Colombia & $\begin{array}{l}\text { This study found that the model } \\
\text { helps to better manage the time of } \\
\text { foreign language classes to favor the } \\
\text { interaction of students and thus } \\
\text { enable practice of their } \\
\text { communication skills. }\end{array}$ & \\
\hline
\end{tabular}

\subsection{The Advantages of Audiovisual Digitization of Learning Resources}

Audiovisual learning resources have been present in the classroom for several decades. Their benefits for the teaching-learning process have been studied and verified by various teachers and experts in educational research. It has been shown that incorporating mobile devices and virtual learning applications in the classroom are highly recommended for a motivating and productive learning environment [13]. Their incorporation is neither an accessory nor an element for stimulating the students. It has been shown that the use of audiovisual language in education is not complimentary; rather, it is the language of the 21st century [14].

Audiovisual materials have an essential characteristic: they stimulate the receiver through two channels: auditory and visual. Unlike a teacher's explanation that is supported by writing on a blackboard or projection of a presentation, the videos add enrichment to teaching with static and moving images, including music, colors, diverse typefaces, and visual and auditory effects. Thus, the teacher can vary the stimulus to the students, capturing their attention and facilitating learning. It has been found that eight of ten young people use videos for educational purposes, including $96 \%$ of those between 14 and 19 years old and $94.6 \%$ of those between 20 and 24 years old [15].

As can be seen, the Flipped Classroom model integrating videos as support material is more familiar and attractive for students of these ages. Table 1 compares this model with the traditional model.

In 2015, the Communication and Education Office of the Autonomous University of Barcelona [14] noted the following benefits of audiovisual resources in teaching: 
1. Favors the observation of reality: Allows accurate representation or recording of events.

2. Facilitates understanding and analysis: Allows observation of reality and visualization of structures, processes, and relationships that can be simply and easily described and captured.

3. Provides a motivating and attractive element for students: Its ease of understanding, realism, and impact (at times) attracts students.

4. Introduces multiple languages and literacies into education: Helps complement the didactic value of oral and written languages.

5. Improves the effectiveness of teaching activities: Improves student performance, making explanations easier by showing various processes.

6. Facilitates the learning of audiovisual writing: Audiovisual language tools help young people adapt and integrate into the contemporary world and acquire skills to express themselves.

7. Enhances media skills and creativity: Students learn technological production, acquire teamwork and problem-solving skills, and develop creativity.

8. Stimulates the use and access to shared resource banks: The teacher is incentivized to use and share materials through various platforms.

9. Promotes the consideration of audiovisual heritage: Students can acquire media skills, enrich their understanding of the environment, and appreciate their own and other people's cultural values.

10. Allows the introduction of aesthetic and creative evaluation criteria: These materials depict reality and allow artistic expression that develops aesthetic skills.

The design of digital resources requires the skills of teachers from three perspectives: didactic, communicative, and technological. This allows the generation of resources in which the content presentation is optimal for students or an audience on a social network. The consolidation of the information and closeness of the language in the video designs result in a better message reception [16].

\subsection{YouTube as an Educational Platform}

One of the most popular social networks in recent years for various purposes, including education, has been YouTube. This platform appeared in 2005 and quickly became the second most trafficked website globally after Google [15]. About one-third of the world's Internet users use YouTube, which generates more than one-and-a-half billion visits per month [17]. The primary users of this content are people between the ages of 18 and 34 who are content creators or consumers. Most maintain a passive attitude as an audience on the platform [18].

The content generators of this social network are called YouTubers, and there are different types, including those who share video game tutorials, miniseries, recipes, music, and humorous scenes [19], and teachers who teach classes on various topics. However, it is essential to note that not everything can be published on this platform. Although it is governed by the principles of freedom of expression and freedom of information, video creators face restrictions, mainly related to violent or sexual content [17].

The educational videos designed for this network have high illustrative, informative, and formative potential for students. They facilitate the orientation and deepening of the subjects beyond the professors' face-to-face classes [20]. This type of video is of great value for social network users because it facilitates the rapid learning of specific academic content, for free. Users become followers who provide recognition and gratitude to YouTubers through comments and likes, creating a stimulating relationship in both directions [15].

It is important to note that, unlike other social networks, the materials shared through YouTube require the use of other video production and editing tools. Among the most popular and easy to use are Powtoon, iMovie, Movie Maker, and YouCut. Therefore, teachers need to learn to handle other software technologies in addition to this social network to share their content. 
YouTube also offers the ability to broadcast live sessions. Through a mobile device or computer camera, content generators can broadcast live, interactive sessions with their audience [17]. In these sessions, the people who connect can comment and ask the YouTuber questions. By answering them, the teachers transmit the message they have designed for the session and have a closer relationship with their followers.

In its use for educational purposes, this tool has motivated the emergence of a new term: edutubers. These are content creators dedicated to instructing others in various topics, both in formal and informal education [19]. Edutubers are not necessarily teachers. As mentioned above, they can be professionals from different areas who share their knowledge.

Teachers who utilize the YouTube platform for educational purposes develop their content with two main objectives: to train the students in the school system to which they belong, and instruct the various users in this social network. Although it may seem that the second case is an example of community service, one must note that YouTube offers the possibility to monetize contributions from creators, obtaining advertising revenue correlated to the number of views generated by each video [19].

This platform is also one of the primary sources of entertainment for students, and therefore they spend several hours a day browsing it [21]. YouTube is an easy, innovative, attractive, and student-friendly tool [22]. Teachers, therefore, often use this platform as a resource to capture the attention of their students and facilitate their learning process, either during face-to-face or virtual classes, or asynchronous sessions self-directed by the student.

\section{Methodology}

\subsection{The Participating Population and the Procedure}

The population participating in this research consisted of 80 second-year high school students at the PrepaTec CCM private school located in Mexico City. Their ages were between 16 and 17 years old; 51 were female and the other 29 were male.

This population participated in a summer course lasting five weeks. The objective was to improve grammatical competency in Spanish. The course enrollment was free. The Department of Spanish and Literature sent an email to all sophomores to invite them to participate. Thus, they were invited to take a free course to reinforce their grammatical competency in their mother tongue during the summer. The condition was that they committed to attending the entire course from the beginning to the end. Due to the availability of teachers, i.e., only three, the number of students was limited to thirty for each teacher. In addition, they completed a Google Form for registration. Eighty students were accepted into the course.

Participating students took a diagnostic test to assess their grammatical competency one week prior to the course and the ILS Index of Learning Style test of learning styles [23]. Both instruments were applied through technological platforms. A synchronous virtual session was established for the grammar test. The learning styles test was answered asynchronously by students individually.

To carry out a more personalized and differentiated instruction, we grouped the population into three levels according to the results obtained in the diagnostic grammar test: basic (28 students, scores from 47 to 64 ), intermediate (27 students, scores 67 to 73 ), and advanced (25 students, scores 76 to 93). Each of the three teachers involved received the results of the learning styles test to classify their students and design learning activities according to the variables considered in the responses: active/reflective, sensitive/intuitive, visual/verbal, and global/sequential.

The course contained over 25 virtual synchronous sessions through the Zoom platform. This tool was selected by the studied educational institution for academic continuity during confinement. In the first session, called class 0 , the students were given the corresponding training to work with the Flipped Classroom model in a virtual modality. In this session, the methodology of the course was presented, and the students were taught to responsibly work with the videos at home: prepare an appropriate space and time to avoid interruptions and improve concentration, pause, repeat, take notes, write down their questions, and 
perform the exercises if any were included in the video. At the end of class 0 , the students received the link to the first YouTube video through the course's WhatsApp group. Thereafter, following each class, the students received the link to the new video that they had to watch that afternoon at home to prepare for the following day's class.

The following 23 synchronous sessions of the course were designed as follows (Table 3), taking as reference the class format for the Flipped Classroom model proposed by Bergmann and Sams [7]:

Table 3. The format used for the design of classes with the Flipped Classroom model.

\begin{tabular}{|c|c|c|}
\hline Activity & Description & Time \\
\hline Opening & $\begin{array}{l}\text { Small warm-up activity that integrates } \\
\text { previous knowledge without yet addressing } \\
\text { the prior topic. }\end{array}$ & $5 \mathrm{~min}$. \\
\hline Q\&A & $\begin{array}{l}\text { Space for student questions on the subject } \\
\text { and questions from the teacher to validate } \\
\text { learning of the subject seen in the video. }\end{array}$ & $5 \mathrm{~min}$. \\
\hline Consolidation, Production & $\begin{array}{l}\text { Activity where students demonstrate their } \\
\text { mastery of the subject; elaboration of } \\
\text { products or execution of diverse activities } \\
\text { assigned according to each student's } \\
\text { learning style. }\end{array}$ & $30 \mathrm{~min}$. \\
\hline Closing & $\begin{array}{l}\text { Clarification of final questions, a quick } \\
\text { summary of what was learned about the } \\
\text { topic, and instructions for the next video } \\
\text { (what should be focused on, how the new } \\
\text { topic should be approached, how to perform } \\
\text { the exercise if there is one, etc.). }\end{array}$ & $10 \mathrm{~min}$. \\
\hline
\end{tabular}

The videos used to teach the topics were previously designed by the Department of Spanish and Literature of the campus (see examples in Appendix A). A video was produced for each topic in the course's educational program. These materials were produced with video design and editing tools: iMovie, Movie Maker, and PowToon. Subsequently, the videos were placed on the YouTube platform. The videos had to have the following characteristics:

- Content: focused solely on the assigned topic, including some reinforcement of prior knowledge, if possible, and with short exercises to reinforce learning.

- Duration: long enough to present the content in a concrete and precise way to adolescent students (between 5 and $10 \mathrm{~min}$, approximately).

- Image: high quality, attractive, and stimulating, adding various colors, illustrations, and visual effects.

- Audio: explanatory; the teacher's voice exposes the subject in a clear, entertaining, and simple way.

- Text: presents the most important content to reinforce the teacher's oral explanation. The general structure of the videos was as follows:

- Greeting: brief welcome to the video and overview of its content.

- Opening: brief recovery of prior knowledge or basis for understanding the topic to be addressed.

- Development: concrete and clear explanation of the topic to be addressed with specific examples; content summarized if necessary and organized logically.

- $\quad$ Reinforcement: short exercises that allow consolidating the subject.

- Closing: brief compilation of what was learned.

To validate the relevance of the videos for this population, we recorded the students reactions to them through electroencephalography (EEG) equipment. Ten students were asked to watch one of the videos because they were all designed with the same characteristics. In this manner, the student's response to the various stimuli of the video was quantitatively evaluated through their brain activity. Jesse [24] and Fernandez-Torre [25] 
note that it is possible to perceive the presence of specific brain waves in some areas of the brain when responding to different types of stimuli, such as, in this case, videos. This is a non-invasive method in which recording electrodes are placed on specific areas of the student's head (see Figure 3). These detect the four brain waves of encephalographic activity: alpha, beta, theta, and delta, whose frequencies and amplitudes can be used as a reference to determine the level of concentration of the students on the video.

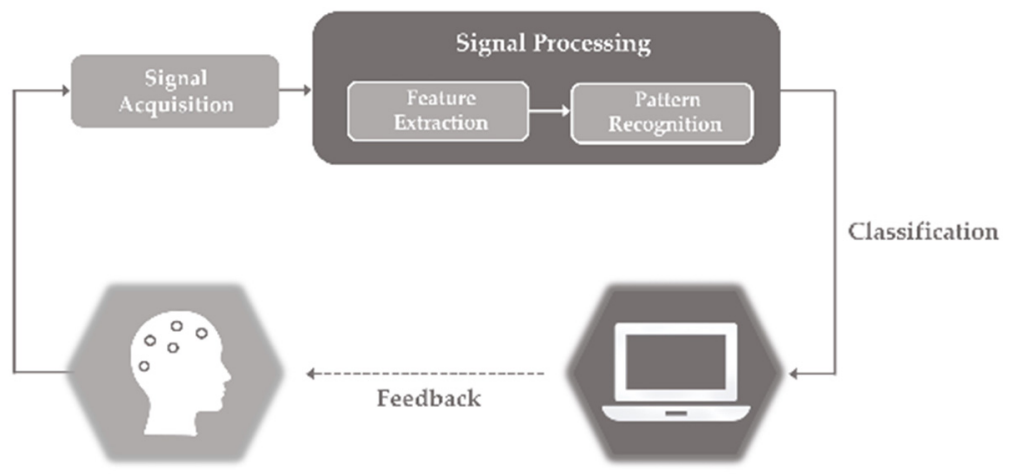

Figure 3. General description of the EEG using a computer.

The brain activity of each electrode was plotted, comparing its amplitude and frequency to determine the brain wave type produced and the area of the brain that generates it. Using color, the graphs indicate the areas where each wave is most likely to occur. The red color indicates the area of highest wave concentration, whereas blue indicates the weakest. By analyzing these records, it was possible to determine at which video time points the student was paying the most attention.

Frequency domain characteristics are related to changes in oscillatory activity. The human EEG can be roughly categorized into 4 frequency bands [26,27]: delta $(1-3 \mathrm{~Hz})$, theta $(4-7 \mathrm{~Hz})$, alpha $(8-12 \mathrm{~Hz})$, and beta $(13-30 \mathrm{~Hz})$ oscillations.

\section{Beta Waves}

These occur when the brain is awake and involved in mental activities. They are broad waves and have the highest transmission speed of the four types. Their frequency ranges between 14 and 30-35 Hz (cycles per second or cps). They denote intense mental activity. When a person is giving a speech, studying, solving a math problem, etc., his brain emits this type of waves.

\section{Alpha Waves}

Alpha waves represent a state of low brain activity and relaxation. These waves are slower and of greater amplitude than the beta waves. Their frequency ranges from 8 to 14 cps. A person who has finished a task and sits down to rest, or is taking a walk or enjoying the landscape, is often in an alpha state.

\section{Theta Waves}

These waves have greater amplitude and lower frequency (between 4 and $8 \mathrm{cps}$ ). They are reached under a state of deep calm. Individuals in this state include those fantasizing (or daydreaming), or someone who, after driving for some time, suddenly realizes that they do not remember how they have driven the last mile. This state is said to be a state of inspiration for creative ideas and solutions, and is a state in which the tasks carried out have been automated; it is no longer necessary to have an attentional and conscious control of their execution.

\section{Delta Waves}

These are the waves with the highest amplitude and lowest frequency (between 1.5 and 4 cps). They are generated in a state of "deep sleep". During sleep, the brain waves change successively from beta to alpha, theta, and finally, delta; these cycles last about $90 \mathrm{~min}$.

Figure 4 shows an experiment on brain activity when a video is played in different video segments. Thus, each signal can be studied to determine the concentration level. 

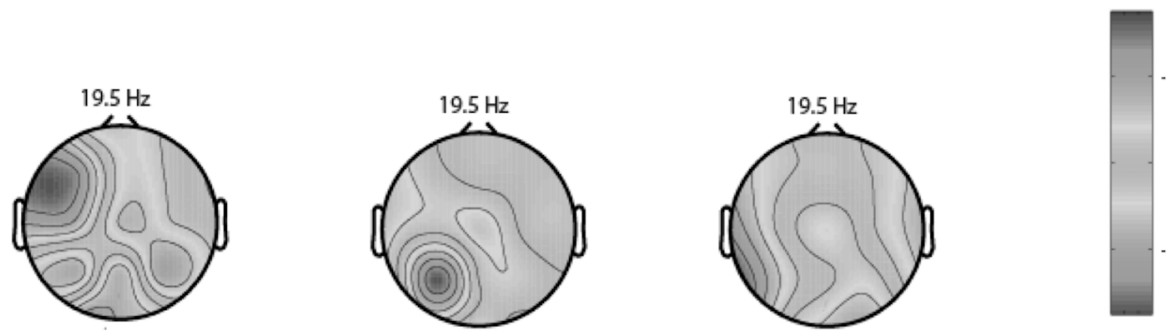

Figure 4. Experimental results regarding the brain activity, recorded during different times of the video. The colored bar shows the power of the signal (frequency of $19.5 \mathrm{~Hz}$ )—darker high power, lighter low power.

In addition to this record, the student's reaction to the videos was also qualitatively evaluated using Emocards [28]. The students' emotions were recorded using a camera when they were stimulated by the video (see Figure 5). This system made it possible to assess the students' perception of the video in terms of attention and emotion.

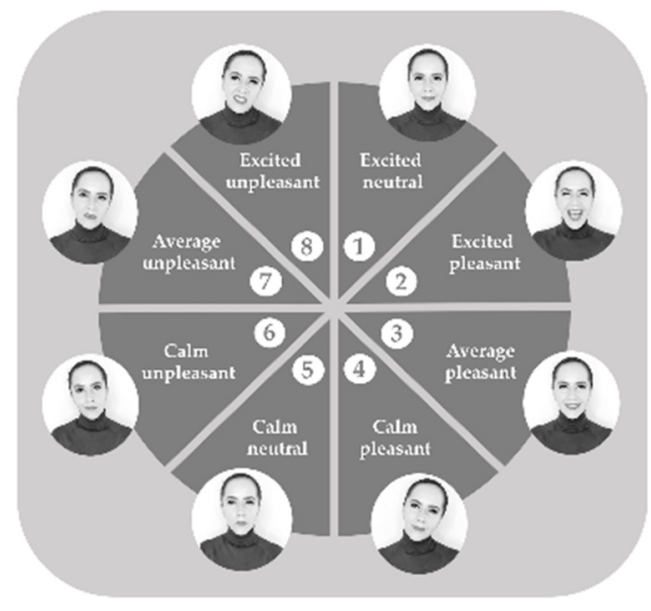

Figure 5. Emocard emotional distribution [28].

This procedure was an essential contribution because the detection of the student's responses offered information about how they were being stimulated audiovisually, and how they were feeling as a result of the presentation of the academic content of the video. Using the student's response, it was possible to design and evaluate the videos. In addition, the videos were able to be made more attractive, thus increasing their adoption. Hence, both processes were used to validate the existing materials and to design more attractive new materials.

Various department professors designed the videos. As a result, the participating professors were required to become familiar with the videos they did not design. In the Results section, the teachers' opinions on this and other items related to implementing the model are presented. This feedback was obtained through an applied survey.

The subject of this study was a pilot course in which a new distance methodology was implemented to improve grammatical competency, and designed to work at three levels (basic, intermediate, and advanced) for a more personalized and differentiated instruction. As a result, only three teachers participated. Their ages ranged between 35 and 45 . Their training was in the Spanish language, at the level of master's studies, and they had between 10 and 15 years of experience working in the educational institution at which the study was carried out. They were familiar with the use of digital resources in teaching and the Flipped Classroom model. 
The design of the learning activities was the responsibility of each participating teacher. According to the learning styles of their students and their teaching style, the teachers designed a menu of specific activities that included these variables: reflective, active, sensitive, intuitive, visual, verbal, global, and sequential.

In the final synchronous session, students took a final test to measure their grammatical proficiency, and the results were compared with those of the first test. Additionally, a survey was used to determine the students' opinions about the course in the virtual Flipped Classroom model supported by videos posted to the YouTube social network.

\subsection{Data Collection}

In this study, the students underwent two standardized tests to measure their grammatical competency, in addition to a learning styles test. Both the students and the teachers also completed an opinion survey at the end of the teaching-learning process.

- Standardized tests to measure grammar competency: Both tests were designed with 45 multiple-choice questions with four answer options. They were applied through Google Forms during 45 min synchronous sessions on the Zoom platform, one prior to starting the course (diagnostic) and another on the last day (final). The students responded on their mobile phones and, through their computer's camera, the teacher monitored the application through the Zoom session. The contents that were evaluated are shown in Table 4.

Table 4. Contents of the standardized tests.

\begin{tabular}{|c|c|}
\hline Topics & Number of Questions \\
\hline $\begin{array}{l}\text { Variable grammatical categories: nouns, articles, pronouns, } \\
\text { adjectives, and verbs }\end{array}$ & 4 \\
\hline $\begin{array}{l}\text { Invariable grammatical categories: conjunctions, prepositions, } \\
\text { adverbs, and interjections }\end{array}$ & 4 \\
\hline Prefixes, lexemes, suffixes, and grammemes & 3 \\
\hline Accentuation & 4 \\
\hline Orthography & 4 \\
\hline $\begin{array}{l}\text { Homographs, homophones, paronyms, synonyms, } \\
\text { and antonyms }\end{array}$ & 3 \\
\hline $\begin{array}{l}\text { The simple sentence and its types: enunciative, interrogative, } \\
\text { exclamatory, optional, imperative, exhortative, doubtful, } \\
\text { and possibility/probability }\end{array}$ & 4 \\
\hline $\begin{array}{l}\text { Syntactic components of the simple sentence: subject } \\
\text { (nucleus and modifiers), predicate (nucleus, direct object, } \\
\text { indirect and circumstantial complements) }\end{array}$ & 4 \\
\hline $\begin{array}{l}\text { Compound sentences: coordinated (copulative, distributive, } \\
\text { disjunctive, and adversative) and juxtaposed }\end{array}$ & 6 \\
\hline $\begin{array}{l}\text { Subordinate clauses: nouns, adjectives, and adverbials } \\
\text { (mode, time, place, condition, consequence, endings, } \\
\text { comparison, and concession) }\end{array}$ & 9 \\
\hline
\end{tabular}

- $\quad$ Learning styles test: The test selected to measure learning styles was the ILS Index of Learning Style in Spanish, prepared by Barbara A. Soloman and Richard M. Felder [23] at North Carolina State University, United States. The test consists of 44 questions that assess the learning styles and classify them into four indicators: active/reflective, sensitive/intuitive, visual/verbal, and global/sequential. The students had five days to answer the test through its official page and report their specific results in a Google Form, where they also uploaded their PDF report sheet obtained from the test site as evidence. This process facilitated the classification of the learning style of each student (see Table 5). 
Table 5. Example of questions from the learning styles test [23].

\begin{tabular}{|c|c|c|}
\hline Questions & & Answer Choices \\
\hline I understand something better after ... & $\begin{array}{l}\mathrm{O} \\
\mathrm{O}\end{array}$ & $\begin{array}{l}\text { trying and testing it. } \\
\text { thinking about it. }\end{array}$ \\
\hline $\begin{array}{l}\text { When I think about what I did yesterday, ___ are } \\
\text { more likely to come to mind. }\end{array}$ & $\begin{array}{l}\mathrm{O} \\
\mathrm{O}\end{array}$ & $\begin{array}{l}\text { images. } \\
\text { words. }\end{array}$ \\
\hline $\begin{array}{l}\text { In a study group working on a difficult topic, I am } \\
\text { more likely to ... }\end{array}$ & $\begin{array}{l}\mathrm{O} \\
\mathrm{O}\end{array}$ & $\begin{array}{l}\text { intervene and provide ideas. } \\
\text { sit down and listen. }\end{array}$ \\
\hline I find it easier ... & $\begin{array}{l}\mathrm{O} \\
\mathrm{O}\end{array}$ & $\begin{array}{l}\text { to learn facts. } \\
\text { to learn the concepts. }\end{array}$ \\
\hline I remember better ... & $\begin{array}{l}\mathrm{O} \\
\mathrm{O}\end{array}$ & $\begin{array}{l}\text { what I see. } \\
\text { what I hear. }\end{array}$ \\
\hline I would rather study ... & $\begin{array}{l}\mathrm{O} \\
\mathrm{O}\end{array}$ & $\begin{array}{l}\text { with a study group. } \\
\text { on my own. }\end{array}$ \\
\hline I am more likely to be considered $a(n) \ldots$ person. & $\begin{array}{l}\mathrm{O} \\
\mathrm{O}\end{array}$ & $\begin{array}{l}\text { extroverted } \\
\text { private }\end{array}$ \\
\hline
\end{tabular}

- Opinion survey for students: The survey was emailed to students via Google Forms, and students were given three days to complete it. The questions asked are shown in Table 6.

Table 6. Opinion survey questions for students about the course taught in the virtual Flipped Classroom model, supported by videos from the YouTube social network.

\begin{tabular}{|c|c|c|}
\hline Questions & & Answer Choices \\
\hline The percentage of the course videos I watched was roughly & $\begin{array}{l}\mathrm{O} \\
\mathrm{O} \\
\mathrm{O} \\
\mathrm{O} \\
\mathrm{O}\end{array}$ & $\begin{array}{l}90 \% \text { to } 100 \% \\
70 \% \text { to } 89 \% \\
50 \% \text { to } 69 \% \\
20 \% \text { to } 49 \% \\
0 \% \text { to } 19 \%\end{array}$ \\
\hline The videos allowed me to understand the course topics. & $\begin{array}{l}\mathrm{O} \\
\mathrm{O} \\
\mathrm{O}\end{array}$ & $\begin{array}{l}\text { Agree } \\
\text { Indecisive } \\
\text { Disagree }\end{array}$ \\
\hline The course activities allowed me to consolidate learning. & $\begin{array}{l}\mathrm{O} \\
\mathrm{O} \\
\mathrm{O}\end{array}$ & $\begin{array}{l}\text { Agree } \\
\text { Indecisive } \\
\text { Disagree }\end{array}$ \\
\hline The learning activities aligned with my learning style. & $\begin{array}{l}\mathrm{O} \\
\mathrm{O} \\
\mathrm{O}\end{array}$ & $\begin{array}{l}\text { Agree } \\
\text { Indecisive } \\
\text { Disagree }\end{array}$ \\
\hline $\begin{array}{l}\text { The methodology used in this course was beneficial in } \\
\text { improving my grammar competency in Spanish. }\end{array}$ & $\begin{array}{l}\mathrm{O} \\
\mathrm{O} \\
\mathrm{O}\end{array}$ & $\begin{array}{l}\text { Agree } \\
\text { Indecisive } \\
\text { Disagree }\end{array}$ \\
\hline
\end{tabular}

- Opinion survey for teachers: The survey was emailed to the participating teachers through Google Forms. The questions asked are shown in Table 7. 
Table 7. Questions from the opinion survey for teachers about the course taught in the virtual Flipped Classroom model, supported by videos from the YouTube social network.

\begin{tabular}{|c|c|c|}
\hline \multicolumn{2}{|l|}{ Questions } & Answer Choices \\
\hline $\begin{array}{l}\text { The percentage of the departmental videos that I used in the } \\
\text { course was }\end{array}$ & $\begin{array}{l}\mathrm{O} \\
\mathrm{O} \\
\mathrm{O} \\
\mathrm{O} \\
\mathrm{O}\end{array}$ & $\begin{array}{l}90 \% \text { to } 100 \% \\
70 \% \text { to } 89 \% \\
50 \% \text { to } 69 \% \\
20 \% \text { to } 49 \% \\
0 \% \text { to } 19 \%\end{array}$ \\
\hline $\begin{array}{l}\text { My opinion about the videos of this course as the primary } \\
\text { didactic materials of the implemented model is that they were }\end{array}$ & $\begin{array}{l}\mathrm{O} \\
\mathrm{O} \\
\mathrm{O} \\
\mathrm{O} \\
\mathrm{O}\end{array}$ & $\begin{array}{l}\text { excellent. } \\
\text { good. } \\
\text { regular. } \\
\text { deficient. } \\
\text { useless. }\end{array}$ \\
\hline $\begin{array}{l}\text { How often did it take ADDITIONAL time to familiarize } \\
\text { myself with the videos? }\end{array}$ & $\begin{array}{l}\mathrm{O} \\
\mathrm{O} \\
\mathrm{O} \\
\mathrm{O} \\
\mathrm{O}\end{array}$ & $\begin{array}{l}\text { Always. } \\
\text { Almost always. } \\
\text { Sometimes. } \\
\text { Rarely. } \\
\text { Never. }\end{array}$ \\
\hline $\begin{array}{l}\text { How much ADDITIONAL time to the length of the video did } \\
\text { I have to step in on average to get familiar with it? }\end{array}$ & $\begin{array}{l}\mathrm{O} \\
\mathrm{O} \\
\mathrm{O} \\
\mathrm{O} \\
\mathrm{O}\end{array}$ & $\begin{array}{l}\text { More than } 20 \mathrm{~min} . \\
\text { Between } 11 \text { and } 20 \mathrm{~min} . \\
\text { Between } 6 \text { and } 10 \mathrm{~min} . \\
5 \text { min or less. } \\
\text { No extra time. }\end{array}$ \\
\hline $\begin{array}{l}\text { The level of participation of my students in preparing with } \\
\text { the videos before the sessions was }\end{array}$ & $\begin{array}{l}\mathrm{O} \\
\mathrm{O} \\
\mathrm{O} \\
\mathrm{O} \\
\mathrm{O}\end{array}$ & $\begin{array}{l}\text { excellent. } \\
\text { good. } \\
\text { regular. } \\
\text { deficient. } \\
\text { null. }\end{array}$ \\
\hline $\begin{array}{l}\text { For the design of the activities, I considered the predominant } \\
\text { learning style of my students. }\end{array}$ & $\begin{array}{l}\mathrm{O} \\
\mathrm{O} \\
\mathrm{O} \\
\mathrm{O} \\
\mathrm{O}\end{array}$ & $\begin{array}{l}\text { Always. } \\
\text { Almost always. } \\
\text { Sometimes. } \\
\text { Rarely. } \\
\text { Never. }\end{array}$ \\
\hline $\begin{array}{l}\text { I feel like I successfully trained my students to learn under the } \\
\text { Flipped Classroom model. }\end{array}$ & $\begin{array}{l}\mathrm{O} \\
\mathrm{o} \\
\mathrm{o}\end{array}$ & $\begin{array}{l}\text { Yes } \\
\text { Indecisive } \\
\text { No }\end{array}$ \\
\hline $\begin{array}{l}\text { From my perspective, the Flipped Classroom model can be } \\
\text { more beneficial than the traditional model for the } \\
\text { development of grammatical competency. }\end{array}$ & $\begin{array}{l}\mathrm{O} \\
\mathrm{o} \\
\mathrm{O}\end{array}$ & $\begin{array}{l}\text { Yes. } \\
\text { Indecisive. } \\
\text { No. }\end{array}$ \\
\hline $\begin{array}{l}\text { What would I modify the Flipped Classroom model } \\
\text { implemented in the } 2020 \text { Summer Course? }\end{array}$ & $\mathrm{O}$ & Various answers \\
\hline
\end{tabular}

\section{Results}

The results obtained from the instruments used in the applied methodology are presented below. These reinforce the model's effectiveness and demonstrate that it can be implemented in a virtual format, although the model was not initially designed for this use. In addition, these results confirm that the different adaptations and elements added to the process, such as the reading of the brain activity and the students' facial expressions, are pertinent, because they provided favorable results. The results of each phase confirm that the complete methodology used and shared here was successful.

The final test results showed that this population's grammatical competency improved significantly after teaching via the Flipped Classroom model. Figure 6 displays the difference between the results obtained in both evaluation instruments. 


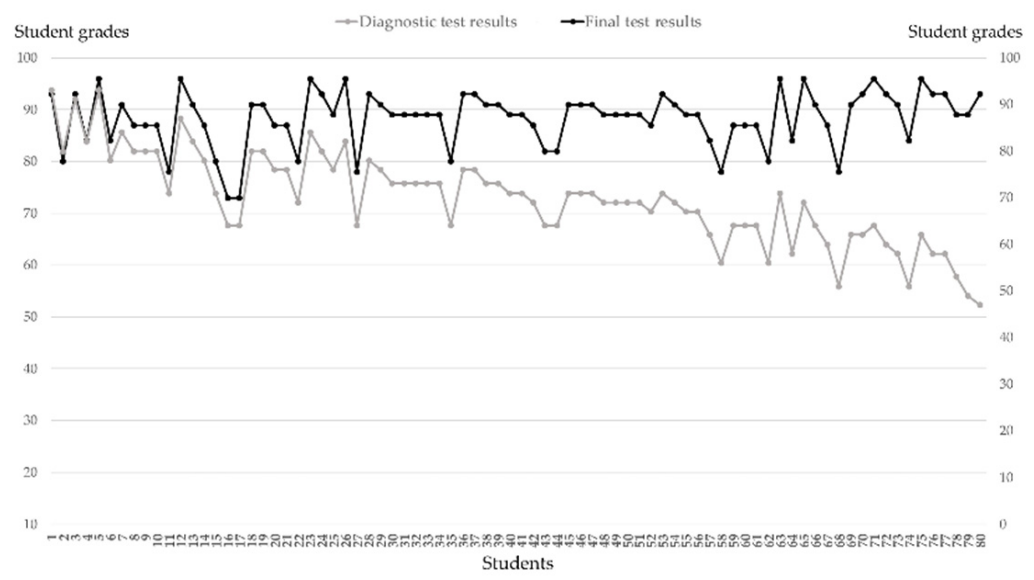

Figure 6. Results of the participating students' diagnostic and final grammar tests in the course implemented with the Flipped Classroom model.

Comparing the two tests shows that 78 of the 80 students increased their scores by between 2 and 46 points, from a total of 100 . Next, the distribution of the improvement points between one test and the other can be observed (Figure 7).

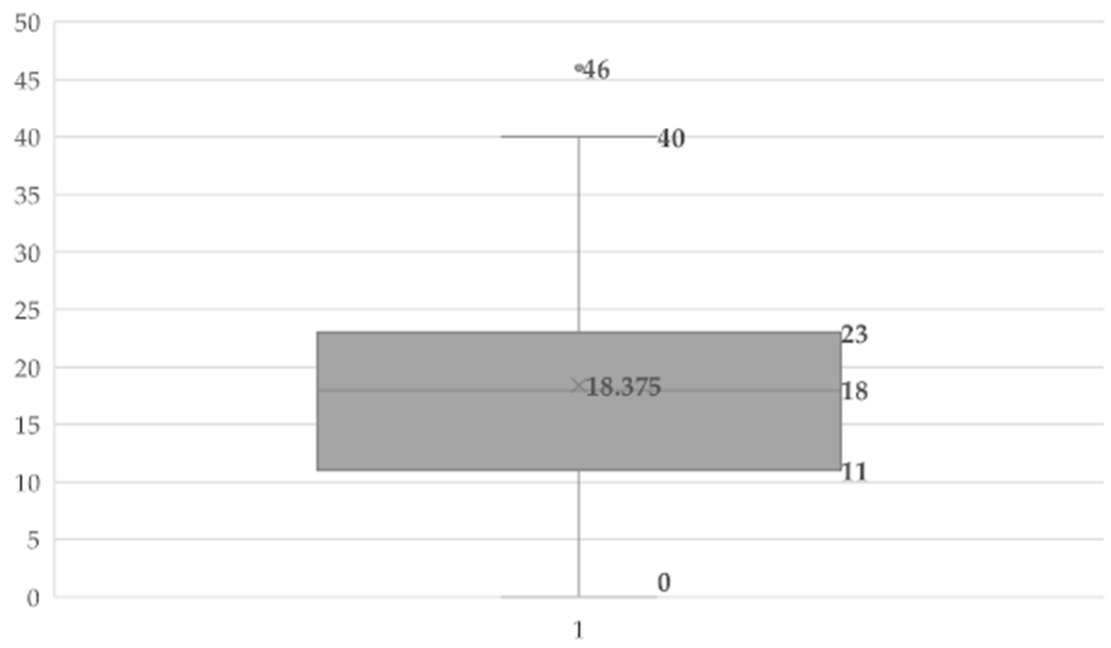

Figure 7. Distribution of progress points between the students' diagnostic and final grammar tests participating in the course implemented with the Flipped Classroom model.

Regarding the students' brain reactions and facial expressions, the results showed that, in general, they enjoyed the videos and stayed focused, particularly during the first few minutes, which is the period during which the most important information was delivered. (see Table 8).

Table 8. Results of the students' concentration level and the Emocards of 10 students watching the video: https://youtu.be/tvABuss7RTM, accessed on 25 August 2021.

\begin{tabular}{|c|c|c|c|}
\hline $\begin{array}{c}\text { EGG } \\
\text { Time 0-3:00 Min } \\
\end{array}$ & $\begin{array}{c}\text { EGG } \\
\text { Time 3:01-5:49 Min }\end{array}$ & $\begin{array}{c}\text { Emocard } \\
\text { Time 0-3:00 Min }\end{array}$ & $\begin{array}{c}\text { Emocard } \\
\text { Time 3:01-5:49 Min }\end{array}$ \\
\hline $\begin{array}{l}8 \text { students maintain } \\
\text { concentration }\end{array}$ & $\begin{array}{l}3 \text { students maintain } \\
\text { concentration }\end{array}$ & $\begin{array}{l}8 \text { students were } \\
\text { pleasantly excited } \\
1 \text { student had } \\
\text { average pleasure }\end{array}$ & $\begin{array}{l}2 \text { students were } \\
\text { pleasantly excited } \\
1 \text { student had } \\
\text { average pleasure }\end{array}$ \\
\hline $\begin{array}{l}2 \text { students could not } \\
\text { maintain concentration }\end{array}$ & $\begin{array}{l}7 \text { students could not } \\
\text { maintain concentration }\end{array}$ & $\begin{array}{l}1 \text { student was } \\
\text { calmly pleasant }\end{array}$ & $\begin{array}{l}7 \text { students were } \\
\text { calmly pleasant }\end{array}$ \\
\hline
\end{tabular}


Regarding the student's opinions about the course they took with the virtual Flipped Classroom model, 76 of the 80 participants answered the survey. The results of the responses are presented below (see Figures 8-12).

Question: The percentage of course videos I watched was about

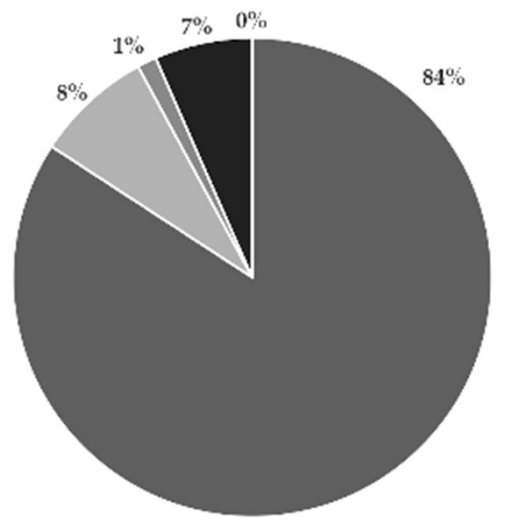

\section{- $90 \%$ to $100 \%$ (almost all or all)}

$=70 \%$ to $89 \%$ (most)

= $50 \%$ to $69 \%$ (half or a little less)

- $20 \%$ to $49 \%$ (very little, less than half)

$=0 \%$ to $19 \%$ (almost none or none)

Figure 8. Percentage of course videos watched by students.

Question: The videos allowed me to understand the course topics.

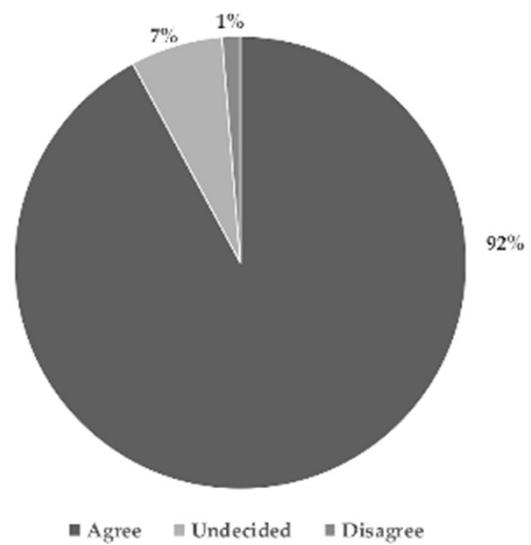

Figure 9. Students' opinions on the adequacy of the videos for their learning.

Question: The course activities allowed me to consolidate learning.

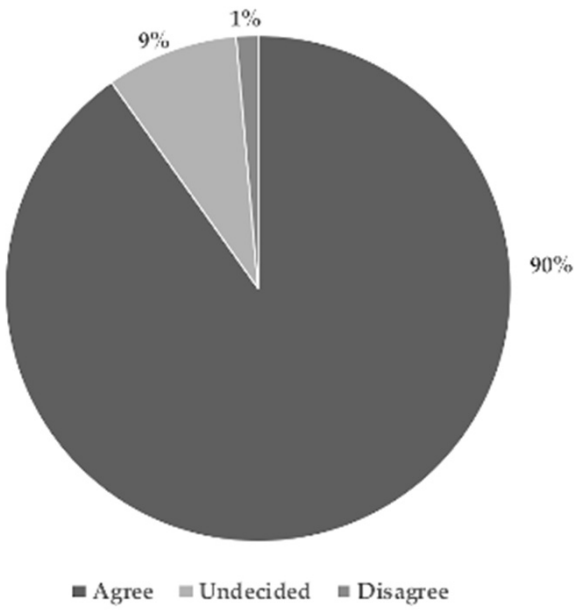

Figure 10. Students' opinions on the effectiveness of learning activities. 
Question: The learning activities aligned with my learning style.

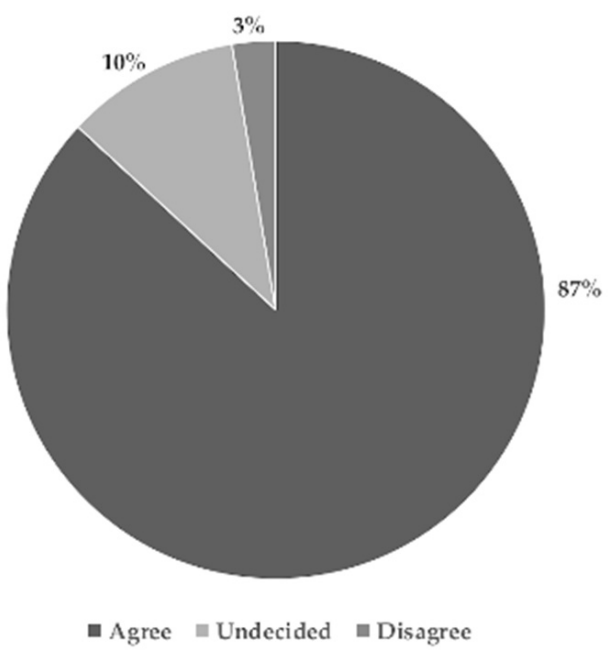

Figure 11. Students' opinions on the consideration of their learning style for the design of learning activities.

Question: The methodology used in this course improved my Spanish grammatical competency.

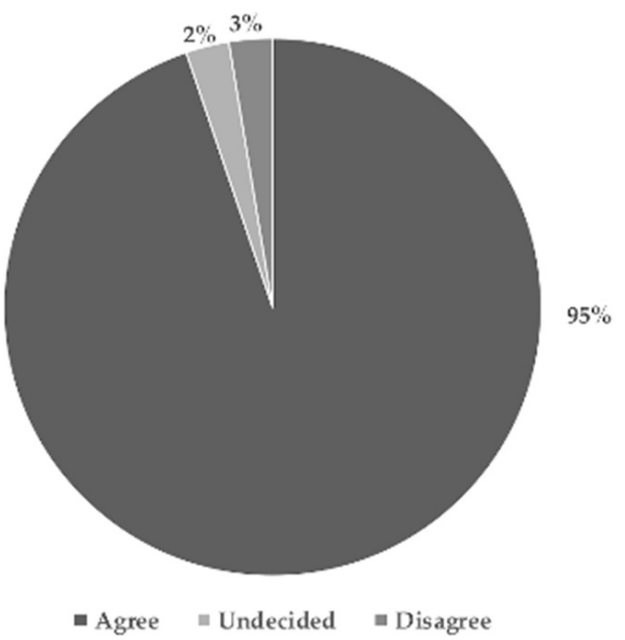

Figure 12. Students' opinions on the relevance of the implemented methodology for developing their grammatical competency in Spanish.

Regarding the opinion of the participating teachers on the implementation of this model, the results are presented in Table 9.

Table 9. The three participating teachers' opinions about the course taught in the virtual flipped classroom model, supported by videos from the YouTube social network.

\begin{tabular}{|c|c|}
\hline Questions & Teachers' Responses \\
\hline $\begin{array}{l}\text { The percentage of the departmental videos that } \\
\text { I used in the course was }\end{array}$ & $90 \%$ to $100 \%$ three professors) \\
\hline $\begin{array}{l}\text { My opinion about the videos of this course as } \\
\text { the primary didactic materials of the } \\
\text { implemented model is that they were }\end{array}$ & $\begin{array}{ll}\text { o } & \text { Excellent. (two professors) } \\
\text { o } & \text { Good. (one professor) }\end{array}$ \\
\hline
\end{tabular}


Table 9. Cont.

\begin{tabular}{|c|c|}
\hline Questions & Teachers' Responses \\
\hline $\begin{array}{l}\text { Did it take ADDITIONAL time to become } \\
\text { familiar with the videos? }\end{array}$ & $\begin{array}{ll}\text { o } & \text { Sometimes (one professor) } \\
\text { o } & \text { Rarely (one professor) } \\
\text { o } & \text { Never (one professor) }\end{array}$ \\
\hline $\begin{array}{l}\text { How much ADDITIONAL time to the length } \\
\text { of the video did I have on average to get } \\
\text { familiar with it? }\end{array}$ & $\begin{array}{ll}\text { o } & \text { Between } 11 \text { and } 20 \mathrm{~min} \text { (one professor) } \\
\mathrm{o} & \text { Between } 6 \text { and } 10 \mathrm{~min} \text { (one professor) } \\
\mathrm{o} & \text { No extra time (one professor) }\end{array}$ \\
\hline $\begin{array}{l}\text { The level of participation of my students in } \\
\text { preparing with the videos before the } \\
\text { sessions was }\end{array}$ & $\begin{array}{l}\text { Excellent. (two professors) } \\
\text { Good. (one professor) }\end{array}$ \\
\hline $\begin{array}{l}\text { For the design of the activities, I considered the } \\
\text { predominant learning style of my students. }\end{array}$ & $\begin{array}{l}\text { Always (two professors) } \\
\text { Almost always (one professor) }\end{array}$ \\
\hline $\begin{array}{l}\text { I feel like I successfully trained my students to } \\
\text { learn under the Flipped Classroom model. }\end{array}$ & Yes (three professors) \\
\hline $\begin{array}{l}\text { From my perspective, the Flipped Classroom } \\
\text { model can be more beneficial than the } \\
\text { traditional model for the development of } \\
\text { grammatical competency. }\end{array}$ & Yes (three professors) \\
\hline $\begin{array}{l}\text { What would I modify from the Flipped } \\
\text { Classroom model implemented in the } 2020 \\
\text { Summer Course? }\end{array}$ & $\begin{array}{l}\text { o More collaborative work among the } \\
\text { teachers } \\
\text { o Specify the terminology of the videos } \\
\text { and evaluation instruments } \\
\text { o Nothing }\end{array}$ \\
\hline
\end{tabular}

\section{Discussion}

This paper presents a successful case in which the Flipped Classroom model was implemented in a virtual format. This model was previously implemented in various educational contexts but in a face-to-face format. The model of the Flipped Classroom was originally designed for face-to-face classes [7]. Here, it was successfully used in a virtual format, thus providing new opportunities for the model. During a contingency such as the COVID-19 pandemic, where educational institutions must transition from face-to-face to virtual class formats, this model is an option for the teaching-learning process. It is also a permanent option for previously existing virtual education formats. In these cases, institutions must undertake crucial considerations and decisions.

Teachers must be trained, and they must feel comfortable breaking their paradigms, enjoy innovations, and work efficiently with digital resources. Teachers should consider that much of the model's effectiveness lies in training students to learn to work independently with the videos and following up on their feedback. Incorporating a learning styles test to understand the profile of the students helps to improve the model, because this allows the design of more relevant activities for the students. It is also essential to consider that the teacher does not necessarily need to learn to design the videos. Teachers can use materials freely available on the Internet, although they must learn to find the most suitable materials for their classes.

We consider that the most valuable part of this article is the presentation of the methodology that was followed. Although the model applied in this study had previously been in use for several years, the model was presented here in a totally virtual format. In addition, we outlined the various steps that can be taken for the implementation of the model and provided recommendations to make it more effective. Additionally, we consider that two of the most important contributions of this work are the reading of brain activity and the facial expressions of students when watching audiovisual materials. This process is of significant relevance to the design of more effective materials and to assess if already existing materials are suitable. 
The reading of both brain activity and facial expressions may have more applications. Various types of metrics can be elaborated with both systems, which can have significant benefits for the teaching-learning process. In this case, through these processes, it was possible to validate the importance of making short videos, of "catching" the students from the beginning, and of presenting the relevant information immediately. This is similar to an inverted pyramid in which the most relevant material, i.e., the base of the content, must be presented at the beginning. In this manner, the least important information is relegated to the end. This address the issue of students paying less attention to the later segments, because the most important information will have already been presented.

The publication of materials on social media is also an important process that helps to measure acceptance. The "likes" and "comments" provided by the audience, specifically highlighting the metrics by age, indicate how each product is perceived.

For future work, we recommend carrying out a comparative study between the virtual Flipped Classroom model, such as the one implemented here, and the traditional model in a virtual format. It would also be of interest to study the application of this model in the virtual format in diverse contexts, with students of different ages and areas of knowledge.

\section{Conclusions}

The findings of this study show that the Flipped Classroom model applied in a virtual format can generate favorable learning results. The standardized test results showed a considerable variation in the students' progress in developing grammar proficiency. The results of the surveys showed student satisfaction with the model, in general, and specifically, students indicated they liked the videos and activities. Most students actively participated in the model, watching the videos and being involved in the activities. In conclusion, the model was liked by, and provided benefit to, the students.

The processes of reading the brain activity and facial expressions of students were proven to be excellent tools for this study. They helped confirm that the materials, although not perfect, were widely accepted by students. Although the opening seconds of the videos caused more impact and resulted in greater acceptance, the students indicated that they liked this type of material and understood the explanations being provided. Significant benefits were found to be provided by the production of short videos that included music, effects, variations in typography and voice, and colorful and moving images. These impacts were considerably greater than those created by a recording of the teacher presenting the class and explaining the subject, as undertaken in the traditional model.

In addition, the teachers also considered the model to be beneficial and relevant for teaching their area of knowledge. The implementation of the model was fluid and, in general, did not cause problems for the teachers.

The physical limitations associated with a virtual format did not present problems in implementing the Flipped Classroom model, despite having been initially designed for a face-to-face class format. This study implemented a variation of the Flipped Classroom model that was proven to be effective for students, and liked by both the students and the teachers. In this paper, we presented the feasibility of using this model to teach via a virtual format and demonstrated that it is a viable teaching option.

Author Contributions: Conceptualization, M.A.S.J.; methodology, M.A.S.J.; validation, M.A.S.J.; formal analysis, M.A.S.J.; investigation, M.A.S.J. and P.P.; resources, M.A.S.J.; data curation, M.A.S.J.; writing-original draft preparation, M.A.S.J.; writing—review and editing, P.P. and E.V.-C.; visualization, P.P.; supervision, P.P.; project administration, M.A.S.J.; funding acquisition, M.A.S.J. All authors have read and agreed to the published version of the manuscript.

Funding: This research was funded by Writing Lab, Institute for the Future of Education, Tecnologico de Monterrey, Mexico.

Data Availability Statement: Not Applicable, the study does not report any data. 
Acknowledgments: The authors would like to acknowledge the financial and technical support of Writing Lab, Institute for the Future of Education, Tecnologico de Monterrey, Mexico, in the production of this work.

Conflicts of Interest: The authors declare no conflict of interest. The funders had no role in the study's design, in the collection, analyses, or interpretation of data, in the writing of the manuscript, or in the decision to publish the results.

\section{Appendix A}

Example of videos designed by the Department of Spanish and Literature:

1. Díaz, A. Acentuación, 2017. https://www.youtube.com/watch?v=bsU9LyZM8QI, accessed on 25 August 2021.

2. Díaz, A. Puntuación, 2017. https://www.youtube.com/watch?v=I-5NQO8DyUw, accessed on 25 August 2021.

3. Díaz, A. Sustantivos, 2017. https://www.youtube.com/watch?v=4agOqIbAYbA\&t= 84s, accessed on 25 August 2021.

4. Sangerman, A. La oración simple: Sus components sintácticos, 2021.https: / / www.yout ube.com/watch?v=tvABuss7RTM\&t=254s, accessed on 25 August 2021.

5. Sangerman, A. La oración simple: Sus tipos, 2020.https://www.youtube.com/watch? $\mathrm{v}=$ bzDFGEAw5w0, accessed on 25 August 2021.

6. Sangerman, A. Oraciones compuestas: Yuxtapuestas, 2020.https: / /www.youtube.com/ watch? $\mathrm{v}=$ amjpjii0NHs\&t=55s, accessed on 25 August 2021.

7. Sangerman, A. Oraciones coordinadas: Sus tipos, 2020.https://www.youtube.com/wa tch?v=K0KTiMFY2Qs\&t=30s, accessed on 25 August 2021.

\section{References}

1. Long, T.; Cummins, J.; Waugh, M. Use of the flipped classroom instructional model in higher education: Instructors' perspectives. J. Comput. High. Educ. 2017, 29, 179-200. [CrossRef]

2. Ramadhani, R.; Umam, R.; Abdurrahman, A.; Syazali, M. The effect of Flipped-Problem Based Learning Model integrated with LMS-Google Classroom for senior high school students. J. Educ. Gift. Young Sci. 2019, 7, 137-158. [CrossRef]

3. $\quad$ Bergmann, J.; Sams, A. Flip your Classroom, 1st ed.; ISTE: Washington, DC, USA, 2012; p. 13.

4. Thai, N.T.T.; De Wever, B.; Valcke, M. The Impact of a Flipped Classroom Design on Learning Performance in Higher Education: Looking for the Best "Blend" of Lectures and Guiding Questions with Feedback. Comput. Educ. 2017, 107, 113-126. Available online: https: / /www.learntechlib.org/p/200447/ (accessed on 25 August 2021). [CrossRef]

5. Chen Hsieh, J.S.; Wu, W.-C.V.; Marek, M.W. Using the flipped classroom to enhance EFL learning. Comput. Assist. Lang. Learn. 2017, 30, 1-21. [CrossRef]

6. Sangermán Jiménez, M.A.; Ponce, P. Differentiated Teaching Based on Standardized Metrics Integrating Fuzzy Logic Type 2 Detection Theory: High School Case-PrepaTec, Mexico. Future Internet 2021, 13, 98. [CrossRef]

7. Bergmann, J.; Sams, A. Dale la Vuelta a tu Clase, 5th ed.; Ediciones SM: Madrid, Spain, 2019; p. 29.

8. Becerra, E.; Quintana, K.; Reyes, E. Aula invertida en tiempos emergentes COVID-19. Rev. Científica Retos De La Cienc. 2020, 4, 24-36.

9. Salido, J.; Salido, P. La Competencia Lingüística en la Comunicación: Visiones Multicisciplinares y Transversalidad, 1st ed.; Ediciones de la Universidad de Castilla-La Mancha: Ciudad Real, Spain, 2019; p. 95.

10. Chilingaryan, K.; Zvereva, E. Methodology of flipped classroom as a learning technology in foreign language teaching. Procedia Soc. Behav. Sci. 2017, 237, 1500-1504. [CrossRef]

11. Núñez-Barroz, S.; Medina-Chicaiza, R. Enseñanza de la gramática del idioma inglés vista a través de una aula invertida. Rev. Científica Cienc. Económicas Y Empresariales 2020, 19, 132-150. [CrossRef]

12. Rudas, C.; Segura, W. Reflexión sobre el uso de las TIC en la metodología del aula invertida en la enseñanza de la lengua extranjera. Rev. Electron. TicALS 2018, 4, 1-14.

13. Suárez-Guerrero, C.; Lloret-Catalá, C.; Mengual-Andrés, S. Teachers' perceptions of the digital transformation of the classroom through the use of tablets: A study in Spain. Comunicar 2016, 24, 81-89. [CrossRef]

14. Gabinete de Comunicación y Educación de la Universidad Autónoma de Barcelona. El Uso Audiovisual en las Aulas, 1st ed.; Editorial Planeta: Barcelona, Spain, 2015; p. 6.

15. Vizccaíno, A.; Contreras, P.; Guzmán, M. Lectura y aprendizaje informal en YouTube: El booktuber. Rev. Científica Educomun. 2019, 59, 95-104.

16. Arias-Ferrer, L.; Egea-Vivancos, A.; Monroy-Hernández, F. Evaluación de recursos audiovisuales para la enseñanza de las ciencias sociales en educación secundaria. Rev. Fuentes 2019, 21, 25-38. [CrossRef] 
17. YouTube. YouTube Social Impact. 2021. Available online: https://socialimpact.youtube.com/why-youtube/ (accessed on 25 August 2021).

18. Bernal, L.; Carvajal, M. Presencia, formatos y estrategia de producción de videos en YouTube: Análisis de caso diario El País. Estud. Sobre Mensaje Periodístico 2020, 26, 25-35. [CrossRef]

19. López, J.; Meza-Córdova, J.; Pacheco, P.; Tusa, F. YouTube en Educación: El Cybersalón de Clases de David Calle. Conf. Proc. UTMACH 2018, 1, 82-90. Available online: http://investigacion.utmachala.edu.ec/proceedings/index.php/utmach/index (accessed on 25 August 2021).

20. Gómez, J. Videos educativos de Youtube para la enseñanza de las ciencias naturales en educación básica colombiana. Rev. ESCENARIOS 2014, 14, 56-81. [CrossRef]

21. Del Valle-Ramón, D.; García-Valcárcel, A.; Gómez-Pablos, V. Aprendeizaje Basado en Proyectos por Medio de la Plataforma YouTube Para la Enseñanza de Matemáticas en Educación Primaria. Educ. Knowl. Soc. 2020, 21, 1-9. Available online: https: / / revistas.usal.es/index.php/eks/article/view/eks20202116/22533 (accessed on 25 August 2021). [CrossRef]

22. Mahasneh, D.; Shoqirat, N.; Singh, C.; Hawks, M. From the classroom to Dr. YouTube: Nursing students' experiences of learning and teaching styles in Jordan. Teach. Learn. Nurs. 2021, 16, 5-9. [CrossRef]

23. Ramírez, F.; Araiza, M.; Felder Silverman-Index Learn. Style En Español Con Interpret. 2016. Available online: http://www.aprend a.mx/ILS.aspx (accessed on 25 August 2021).

24. Jessy, P. Analysis of EEF Signals for EEF-Based Brain-Computer Interface. Available online: https://www.semanticscholar.org/ paper / Analysis-of-EEG-Signals-for-EEG-based-Interface-Jessy / ccb7515f8f9f9e018b5c62315ece21a979895bec?sort=relevance\& citationIntent=methodology (accessed on 25 August 2021).

25. Fernandez-Torre, J. Electroencefalograma normal durante la vigilia. In Manual de Electroencefalografía, 1st ed.; McGraw-Hill Interamericana: Guaynabo, Spain, 2002; p. 35.

26. Ponce, P.; Molina, A.; Balderas, D.C.; Grammatikou, D. Brain Computer Interfaces for Cerebral Palsy. Available online: https: //www.intechopen.com/chapters/46001 (accessed on 25 August 2021).

27. Balderas, D.; Molina, A.; Ponce, P. Alternative classification techniques for brain-computer interfaces for smart sensor manufacturing environments. IFAC-Pap. 2015, 48, 680-685. [CrossRef]

28. Hekkert, P.; Desmet, P. The Basis of Product Emotions. Available online: https://www.semanticscholar.org/paper/The-Basis-of -Product-Emotions-Hekkert-Desmet/66420e3bbb609e0ccfeead5877f9eb12f404c7fc (accessed on 25 August 2021). 